\title{
Lignin peroxidase mediated silver nanoparticle synthesis in Acinetobacter sp.
}

\author{
Richa Singh ${ }^{1}$, Utkarsha U. Shedbalkar ${ }^{2}$, Shradhda B. Nadhe ${ }^{1}$, Sweety A. Wadhwani ${ }^{1}$ and Balu A. Chopade ${ }^{1,3^{*}}$
}

\begin{abstract}
Metals present in environment render the bacteria to attain certain resistance machinery to survive, one of which is transformation of metal ions to nano forms. Various enzymes and proteins have been suggested to play significant role in synthesis of silver nanoparticles (AgNPs) in bacteria. In present study, we have purified lignin peroxidase from secreted enzyme extract of Acinetobacter sp. employing diethyl aminoethyl cellulose ion exchange and Biogel P-150 gel filtration column chromatography. The purified fraction has a specific activity of $1.571 \mathrm{U} / \mathrm{mg}$ with substrate $n$-propanol and 6.5-fold purification. The tetrameric enzyme, with molecular weight of $99 \mathrm{kDa}$, consisted of dimers of two polypetides of 23.9 and $24.6 \mathrm{kDa}$ as revealed by native and SDS-PAGE. On exposure to purified enzyme, spherical polydispersed AgNPs of $\sim 50 \mathrm{~nm}$ were obtained as observed under transmission electron microscope. Optimum activity of the purified enzyme was obtained at $\mathrm{pH} 2$ and $60^{\circ} \mathrm{C}$ with $n$-propanol as substrate. This is the first report describing the reduction of extracellular silver ions by lignin peroxidase purified from Acinetobacter sp.
\end{abstract}

Keywords: Silver nanoparticles, Acinetobacter, Lignin peroxidase, Purification, PAGE

\section{Introduction}

Acinetobacter species are aerobic, non-motile and Gram negative coccobacilliary bacteria (Huddedar et al. 2002; Pardesi et al. 2007; Singh et al. 2016; Towner and Chopade 1987). They are quite versatile with respect to genetic organization, nutrition and metabolism leading their ubiquitous presence in soil, water, food, industrial wastes, sludge, human skin, respiratory mucus membrane, etc. (Jagtap et al. 2010; Patil and Chopade 2000; Rokhbakhsh-Zamin et al. 2011; Sachdev et al. 2010; Saha and Chopade 2002; Yavankar et al. 2007; Yele et al. 2012). Bacteria encounter various metals and metalloids, such as copper, zinc, manganese, vanadium, chromium, molybdenum, silver, iron, cobalt, nickel, etc. in nature. Some of these ions are required for structural or catalytic functions in bacteria while others have detrimental effect (Deshpande et al. 1993; Shakibai et al. 1998, 1999). To thrive in such conditions, bacterium attains certain genetic and biochemical mechanisms, such as extracellular binding, precipitation, segregation and complexation

\footnotetext{
*Correspondence: bachopade@gmail.com; vc@bamu.ac.in

${ }^{3}$ Dr. Babasaheb Ambedkar Marathwada University, Aurangabad 431004, India

Full list of author information is available at the end of the article
}

by thiol-containing molecules, intracellular deposition, solubility variation and alteration in toxicity by changing redox state of the metal ion (Deshpande and Chopade 1994; Dhakephalkar and Chopade 1994; Singh et al. 2015). Absence of specific metal transporter system or any cellular efflux pumping systems has also been suggested to prevent metal ion deposition in lethal concentration inside the cells (Das and Marsili 2010). Moreover, transformation of metal ions to nanoparticles may also act in favor of microorganisms (Duran et al. 2011).

Acinetobacter strains are capable of synthesizing large number of metal nanoparticles, such as silver, gold, selenium, platinum, etc. (Gaidhani et al. 2013; Singh et al. 2013; Wadhwani et al. 2014, 2016). Reduction of silver ions to silver nanoparticles (AgNPs) is of particular interest for Acinetobacter spp. that are known to exhibit plasmid-mediated silver resistance (Deshpande and Chopade 1994). Moreover, Acinetobacter strains have also been reported to possess a cysteine-rich metalloprotein, which aid in binding and accumulating silver ions intracellularly without any toxicity (Shakibai et al. 2003). In our earlier study, we demonstrated the production of extracellular AgNPs employing secreted enzymes in Acinetobacter sp. (Singh et al. 2013). The available literature 
on bacteriagenic AgNPs suggested the role of NADHdependent enzymes, especially nitrate reductase, in reduction of silver ions to nano silver (Kalimuthu et al. 2008; Karthik et al. 2014). However, Acinetobacter spp. do not produce nitrate reductase enzyme, the fact supported by the study of Gaidhani et al. (2013), where nitratereductase independent synthesis of AgNPs was reported. Nitrogenase and hydrogenase enzymes have been implicated in formation of silver nanoparticles in cyanobacteria (Brayner et al. 2007). Besides this, the reducing cofactors generated by spore-associated enzymes, such as alkaline phosphatase, glucose oxidase, catalase and laccase, can also mediate AgNP synthesis in bacteria (Hosseini-Abari et al. 2013). In one of the non-biological processes, conjugate of streptavidin-horseradish peroxidase (HRP) has been demonstrated to stimulate growth of AgNPs on a silicon surface (Schneidewind et al. 2012).

Since extract of secreted organic compounds by Acinetobacter sp. is capable of synthesizing extracellular AgNPs (Singh et al. 2013), we propose that this secretory material has vital proteins, including enzymes, and other biomolecules released by Acinetobacter sp. while growing. These organic molecules may act as reducing agents to convert silver ions to AgNPs. In view of this, the present study deals with the purification and biochemical characterization of one of the proteins involved in AgNP synthesis in Acinetobacter sp. The purified protein was evaluated for its potential activity in reduction of silver ions to AgNPs.

\section{Materials and methods \\ Chemicals}

Luria-Bertani (LB) broth, agar, catechol, veratryl alcohol, magnesium sulfate, zinc sulfate, copper sulfate, ammonium sulfate, silver chloride, mercuric chloride, calcium chloride, sodium chloride, dipotassium hydrogen phosphate, potassium dihydrogen phosphate, silver nitrate, sodium nitrate, potassium nitrate, ammonium nitrate and sodium thiosulfate, sulfanilamide, $N$-(1-naphthyl) ethylenediamine dihydrochloride (NEDD), 2,2'-Azinobis(3-ethylbenzothiazoline-6-sulfonic acid) diammonium salt (ABTS), Diethyl aminoethyl (DEAE)-cellulose and Biogel P-150 were procured from Himedia (Mumbai, India). Coomassie brilliant blue R-250, hydrogen peroxide and $n$-propanol were obtained from Loba Chemie (Mumbai, India), SD Fine (Mumbai, India) and Qualigens (Mumbai, India), respectively. Ammonium sulphate, $\mathrm{NADH}, \mathrm{L}-\mathrm{DOPA}$, guaiacol, hydroxyquinolone and tartaric acid were supplied by SRL Pvt Ltd (Mumbai, India).

\section{Preparation of secreted enzyme extract}

Acinetobacter sp. (MCC 3391), isolated from wheat rhizosphere, was routinely cultured in LB broth. Prior to inoculation for experiments, a loopful of culture from LB agar plate was inoculated in $10 \mathrm{ml} \mathrm{LB}$ broth in tube and incubated overnight at $37{ }^{\circ} \mathrm{C} / 150 \mathrm{rpm}$ to obtain logphase metabolically active bacterial cells.

The secreted enzyme (SE) extract of $72 \mathrm{~h}$ cultivation, reported to produce silver nanoparticles, has been prepared as per the protocol described in our earlier study (Singh et al. 2013). Briefly, OD adjusted $\left(\mathrm{OD}_{600} \sim 1.0\right)$ overnight grown log-phase culture of Acinetobacter sp. was inoculated in $250 \mathrm{ml}$ flask containing $100 \mathrm{ml} \mathrm{LB}$ broth $(1 \% \mathrm{v} / \mathrm{v})$ and incubated at $30{ }^{\circ} \mathrm{C} / 150 \mathrm{rpm}$ for $24 \mathrm{~h}$. The cells were harvested by centrifugation and resuspended in sterile distilled water after thorough washing. These were then incubated at $30^{\circ} \mathrm{C} / 150 \mathrm{rpm}$. After $72 \mathrm{~h}$, centrifugation was done and cell pellet was discarded. SE extract was collected by passing the supernatant obtained after centrifugation through a $0.2 \mu \mathrm{m}$ membrane filter (Pall Corporation, NY, USA) and stored at $4{ }^{\circ} \mathrm{C}$ until further use.

\section{Protein estimation and enzyme activity}

Protein was determined by Folin-Lowry method (Lowry et al. 1951), using bovine serum albumin as a standard.

Nitrate reductase activity in SE extract was determined by incubating the extract with $10 \mathrm{mM}$ potassium nitrate and $2 \mathrm{mM} \mathrm{NADH}$ for $2 \mathrm{~min}$ at $30^{\circ} \mathrm{C}$ followed by addition of $50 \mathrm{mM}$ sulphanilamide (prepared in $3 \mathrm{M}$ hydrochloric acid) and $77 \mathrm{mM}$ NEDD. The positive nitrate reductase activity was detected by presence of pink color, the absorbance of which was measured at $540 \mathrm{~nm}$. Suitable blanks were also maintained.

Laccase enzyme activity was determined using $0.1 \%$ ABTS as a substrate in acetate buffer $(0.1 \mathrm{M}, \mathrm{pH} 4)$. One unit of enzyme activity was defined as the amount of enzyme required to oxidize $1 \mu \mathrm{mol}$ of substrate in $1 \mathrm{~min}$, which was measured by reading absorbance at $420 \mathrm{~nm}$ for $1 \mathrm{~min}$.

Lignin peroxidase activity was measured using n-propanol as a substrate as per the protocol described earlier (Kalyani et al. 2011). The reaction mixture contained $40 \mathrm{mM}$-propanol, $2 \mathrm{mM}$ hydrogen peroxide and $50 \mathrm{mM}$ tartaric acid. One unit of enzyme activity was defined as the amount of enzyme required to oxidize $1 \mu \mathrm{mol}$ of substrate per minute. It is measured by reading absorbance at $310 \mathrm{~nm}$ for $1 \mathrm{~min}$.

\section{Preparation of crude enzyme}

The SE extract was subjected to ammonium sulphate precipitation to obtain $60 \%$ saturation in cold conditions. The solution was then centrifuged to collect the precipitates, which were further dialyzed against phosphate buffer ( $\mathrm{pH}$ 7.8) to remove ammonium sulphate. 


\section{Purification of enzyme}

\section{DEAE-cellulose ion exchange chromatography}

The dialyzed crude preparation was loaded onto a preactivated DEAE-cellulose column $(15 \times 2 \mathrm{~cm})$ equilibrated with $50 \mathrm{mM}$ phosphate buffer ( $\mathrm{pH} 7.8)$. The column was washed with same buffer and further elution was carried out using linear gradient of 0.2 to $1.0 \mathrm{M} \mathrm{NaCl}$ solution. Fractions containing lignin peroxidase activity were dialyzed against distilled water.

\section{Biogel P-150 gel filtration chromatography}

The dialyzed fraction was concentrated to $1 \mathrm{ml}$ in sucrose and loaded on a Biogel P-150 column $(45 \times 0.8 \mathrm{~cm})$ equilibrated with phosphate buffer $(\mathrm{pH} 7.8)$ and eluted with same buffer at a flow rate of $3 \mathrm{ml} / \mathrm{h}$. Fractions containing lignin peroxidase activity were pooled, dialyzed against distilled water and stored at $4{ }^{\circ} \mathrm{C}$ until further use.

\section{Polyacrylamide gel electrophoresis (PAGE)}

Native and sodium dodecyl sulphate (SDS)-PAGE was performed with $4 \%$ stacking and $10 \%$ resolving gel using vertical gel electrophoresis system (GeNei, Bangalore, India). Silver staining was performed in native PAGE and molecular mass of the purified peroxidase was determined by calculating the relative mobility of standard protein molecular weight marker (GeNei) run alongside. In SDS PAGE, protein bands were stained with $0.1 \%(\mathrm{w} / \mathrm{v})$ coomassie brilliant blue R-250 prepared in methanol:acetic acid:distilled water $(\mathrm{v} / \mathrm{v})(4: 1: 5)$ for $3 \mathrm{~h}$ at room temperature. The gel was further destained with solution containing methanol:acetic acid:distilled water $(\mathrm{v} / \mathrm{v})(4: 1: 5)$ and the bands were analyzed with respect to the standard protein molecular weight marker (Sigma).

\section{AgNP synthesis by purified protein}

Synthesis of AgNP by purified enzyme was carried out by addition of $0.07 \mathrm{mg}$ enzyme, having $0.1 \mathrm{U}$ of lignin peroxidase activity, to $1 \mathrm{mM}$ silver nitrate solution in total reaction volume of $1 \mathrm{ml}$. The spectrum was measured over the wavelength range of 200-800 $\mathrm{nm}$ after regular intervals till $24 \mathrm{~h}$. It was further analyzed under transmission electron microscope (TEM), dynamic light scattering (DLS) and energy dispersive spectroscopy (EDS) for morphological and compositional characteristics.

\section{Determination of optimum $\mathrm{pH}$ and temperature}

The effect of $\mathrm{pH}$ on activity of $0.1 \mathrm{U}$ of purified enzyme was assayed within a $\mathrm{pH}$ range of 1-10 using $40 \mathrm{mM}$ $n$-propanol as a substrate and $50 \mathrm{mM}$ of the following buffers: $\mathrm{HCl}-\mathrm{KCl}$ buffer $(\mathrm{pH} 1)$, tartaric acid $(\mathrm{pH}$ $2)$, citrate buffer $(\mathrm{pH} 3)$, acetate buffer $(\mathrm{pH} 4-5)$, phosphate buffer ( $\mathrm{pH} 6-8)$, tris- $\mathrm{HCl}$ buffer $(\mathrm{pH}$ 9) and carbonate-bicarbonate buffer ( $\mathrm{pH} 10)$. Optimum temperature of the enzyme $(0.1 \mathrm{U})$ was determined over the temperature range of $10-90{ }^{\circ} \mathrm{C}$ with $40 \mathrm{mM} n$-propanol as substrate at its optimal $\mathrm{pH}$ value. The experiments were performed in duplicate and the values are expressed as mean \pm standard deviation.

\section{Effect of salts}

Fifteen salts, including magnesium sulfate, zinc sulfate, copper sulfate, ammonium sulfate, silver chloride, mercuric chloride, calcium chloride, sodium chloride, dipotassium hydrogen phosphate, potassium dihydrogen phosphate, silver nitrate, sodium nitrate, potassium nitrate, ammonium nitrate and sodium thiosulfate, were added to the reaction mixture to obtain final concentration of $25 \mathrm{mM}$. Lignin peroxidase activity $(0.1 \mathrm{U})$ was determined using $40 \mathrm{mM} n$-propanol as substrate using the protocol described earlier.

\section{Substrate specificity}

Substrate specificity of peroxidase was checked by using $40 \mathrm{mM}$ of various substrates, such as $n$-propanol, L-DOPA, guaiacol, hydroxyquinone, catechol and veratryl alcohol, prepared in double distilled water. The specific activity of enzyme was estimated through spectroscopic measurement of oxidation of substrates by enzyme at specific wavelength.

\section{Results}

Enzyme activity in SE extract

Previously, we showed extracellular synthesis of AgNPs employing SE extract of Acinetobacter sp. MCC 3391 (Singh et al. 2013). In present study, the bacterial SE extract was tested for presence of nitrate reductase, laccase and lignin peroxidase. SE extract showed positive activity for lignin peroxidase. However, no nitrate reductase and laccase activity was detected.

\section{Purification of lignin peroxidase}

To investigate the role of bacterial lignin peroxidase, present in SE extract, in synthesis of AgNPs, the enzyme was purified in two steps using column chromatography. Figure 1 represents the elution profile of the crude enzyme loaded on DEAE-cellulose anion exchanger column where linear gradient of $0.2-1.0 \mathrm{M} \mathrm{NaCl}$ was used as eluent. Although both fraction nos. 33 and 51 exhibited lignin peroxidase activity, fraction no. 33 had the higher specific activity and synthesized AgNPs faster as compared to fraction no. 51. Fraction no. 33 was further concentrated and loaded on Biogel P-150 gel filtration column. The elution profile has been shown in Fig. 2. Here, fraction no. 12 showed the lignin peroxidase activity. 


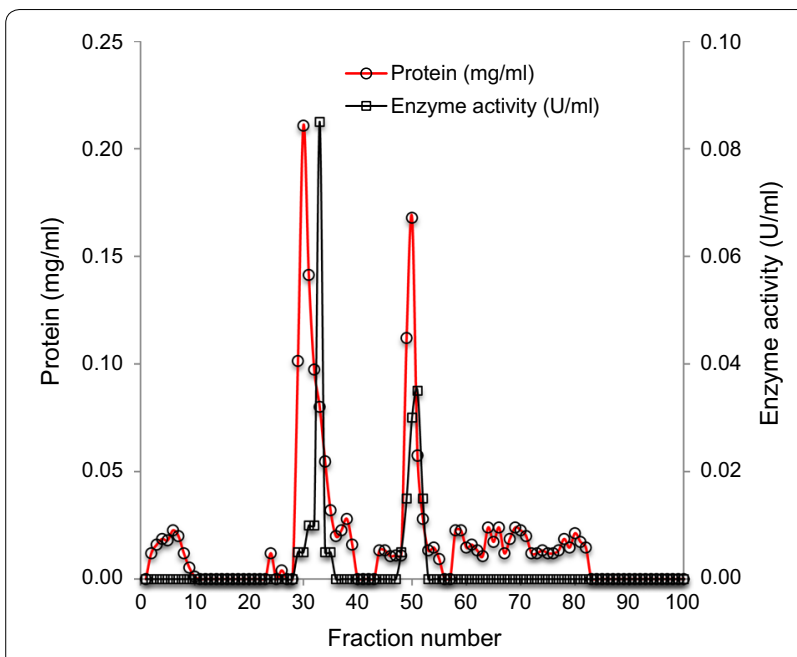

Fig. 1 Elution profile of lignin peroxidase by DEAE-cellulose ion exchange chromatography

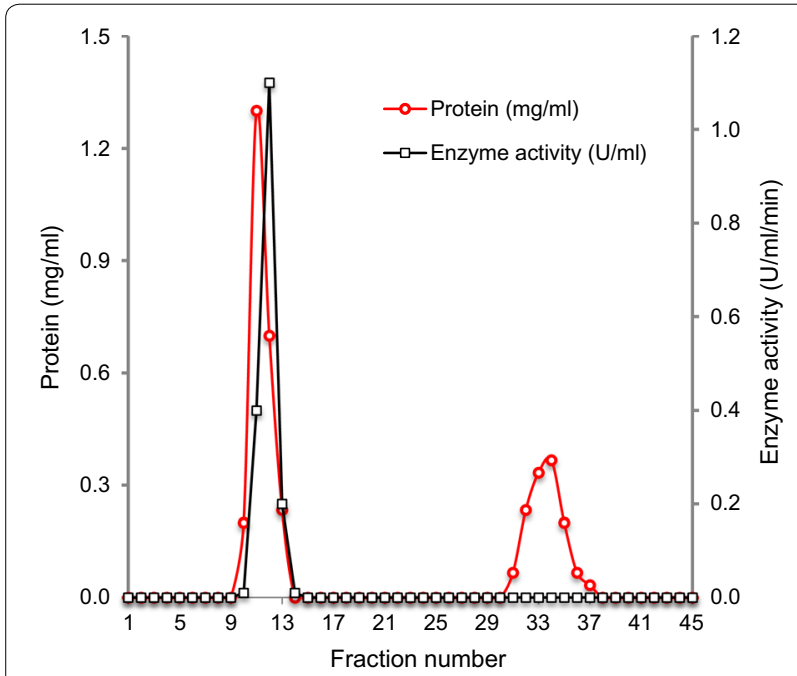

Fig. 2 Elution profile of lignin peroxidase by Biogel P-150 gel filtration chromatography

Table 1 summarizes the purification profile of the enzyme. The crude enzyme contained a total of $165 \mathrm{mg}$ protein corresponding to $40 \mathrm{U}$ of bacterial lignin peroxidase activity with $n$-propanol as substrate. Further with two-step purification by DEAE-cellulose anion exchanger and Biogel P-150 gel filtration chromatography, the fraction with 6.5-fold increased peroxidase activity was obtained having protein concentration of $0.7 \mathrm{mg} / \mathrm{ml}$ and specific activity of $1.571 \mathrm{U} / \mathrm{mg}$.

\section{PAGE}

The fraction no. 12, as obtained by gel filtration chromatography, showed a single band on native-PAGE stained by silver. The molecular mass of the purified fraction was $99 \mathrm{kDa}$ (Fig. 3a). Further, the fraction was subjected to denaturation and analyzed on SDS-PAGE. Two bands, corresponding to molecular mass of 23.9 and $24.6 \mathrm{kDa}$, were seen (Fig. 3b).

\section{AgNP synthesis by purified lignin peroxidase}

Synthesis of AgNPs by purified lignin peroxidase was carried out. Exposure of purified lignin peroxidase to silver nitrate resulted in synthesis of AgNPs indicated by color change of the reaction medium to brown (Fig. 4). This change in color was observed within $6 \mathrm{~h}$. An SPR peak at $400 \mathrm{~nm}$ was also observed in UV-Vis spectrum taken after $24 \mathrm{~h}$ confirming the conversion of silver ions to AgNPs (Fig. 4). No further increase in peak was observed after $24 \mathrm{~h}$ indicating complete reduction of silver ions to nanoparticles. Further, polydispersed spheres of nanoparticles of size $\sim 50 \mathrm{~nm}$ were observed under TEM (Fig. 5a). The nanoparticles were seen to be present in both dispersed and aggregated forms, which was also confirmed by particle size distribution (Fig. 5b). There was no apparent effect of time of incubation on morphology of nanoparticles. EDS spectrum revealed a peak at $3 \mathrm{keV}$ (Fig. 5c).

\section{Optimum $\mathrm{pH}$ and temperature}

The $\mathrm{pH}$ optimum of purified lignin peroxidase that catalyzed $n$-propanol oxidation was found to be 2.0 (Fig. 6). The specific activity decreased as the $\mathrm{pH}$ fell in alkaline range. The lignin peroxidase activity was observed at the temperature ranging from 10 to $90^{\circ} \mathrm{C}$ indicating the great thermostability of the enzyme (Fig. 7). The optimum temperature with $n$-propanol was found to be $60^{\circ} \mathrm{C}$.

\section{Effect of salts}

Effect of various salts on the activity of purified lignin peroxidase was tested with $n$-propanol as substrate

Table 1 Purification profile of lignin peroxidase from SE extract of Acinetobacter sp.

\begin{tabular}{lllll}
\hline Purification stage & Enzyme activity $(\mathbf{U})$ & Total protein $(\mathbf{m g})$ & Specific activity (U/mg) & Purification fold \\
\hline Crude & 40 & 165 & 0.242 & 1.0 \\
DEAE-cellulose anion exchanger & 6.35 & 6.07 & 1.062 & 4.4 \\
Biogel P-150 gel filtration & 1.10 & 0.70 & 1.571 & 6.5 \\
\hline
\end{tabular}




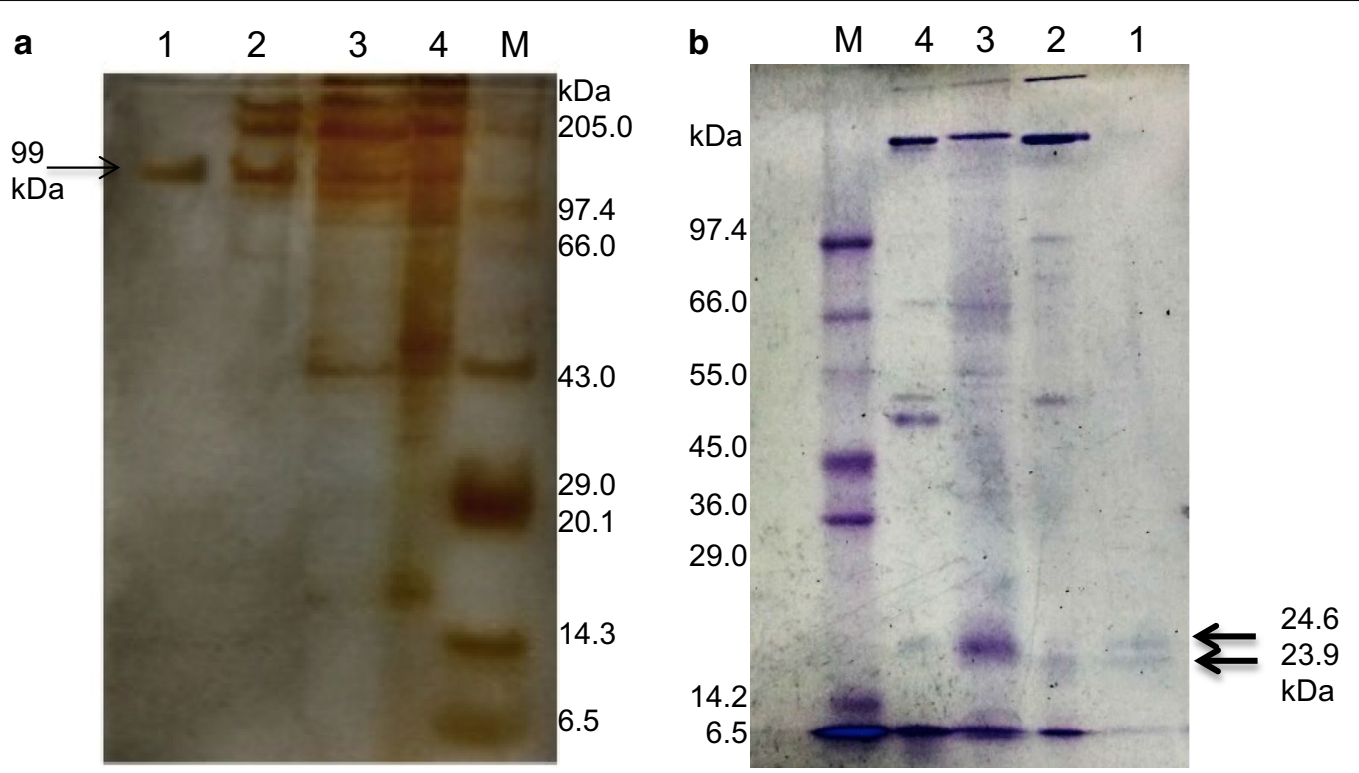

Fig. 3 PAGE of purified enzyme fraction. a Native PAGE, and $\mathbf{b}$ SDS-PAGE. Lanes: 1 Biogel fraction, 2 DEAE-cellulose fraction, 3 ammonium sulphate precipitation (crude enzyme), 4 SE extract and M marker

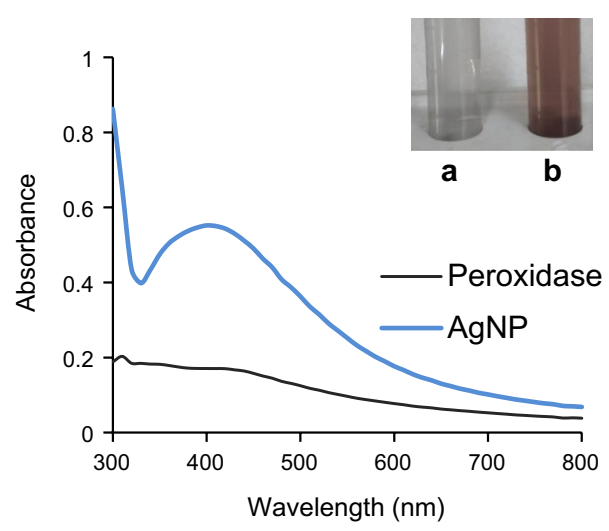

Fig. 4 UV-Vis spectrum of purified lignin peroxidase and synthesized AgNPs. Inset: Color change showing AgNP synthesis by purified enzyme on addition of silver nitrate $\mathbf{a}$ control, and $\mathbf{b}$ after AgNP synthesis
(Table 2). Maximum enhancement in peroxidase activity was observed with magnesium sulfate followed closely by silver nitrate. These salts appear to act as good activators of enzyme activity. In general, addition of sulfate and nitrate ions increases the activity of the enzyme except when they are present in conjunction with ammonium ions. Ammonium salts, such as ammonium nitrate and ammonium sulfate, were found to inhibit the peroxidase activity. Chloride and phosphate salts also reduced the activity of the enzyme to some extent.

\section{Substrate specificity}

Substrate specificity of the purified lignin peroxidase was determined with various substrates (Table 3 ). The activity was found to be maximum with $n$-propanol closely followed by guaiacol, catechol and veratryl alcohol. No activity was detected with hydroxyquinone.

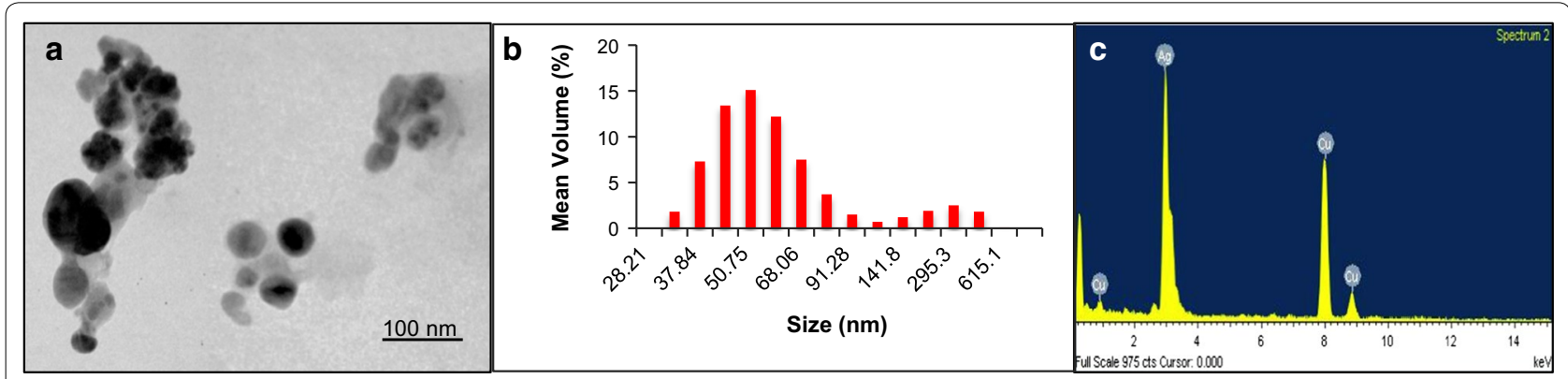

Fig. 5 Characterization of AgNPs synthesized by purified lignin peroxidase by $\mathbf{a} T E M, \mathbf{b}$ particle size distribution, and $\mathbf{c}$ EDS 


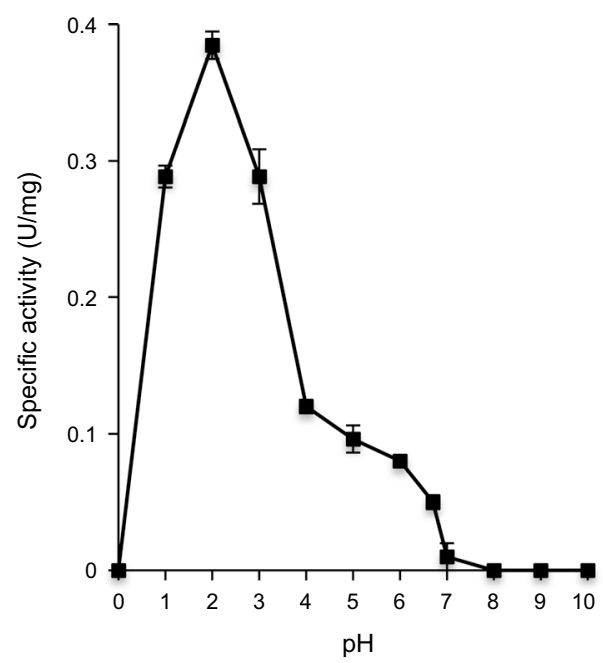

Fig. 6 Optimum $\mathrm{pH}$ for lignin peroxidase with $n$-propanol as substrate. The experiment was done in duplicate and the values are expressed as mean \pm SD

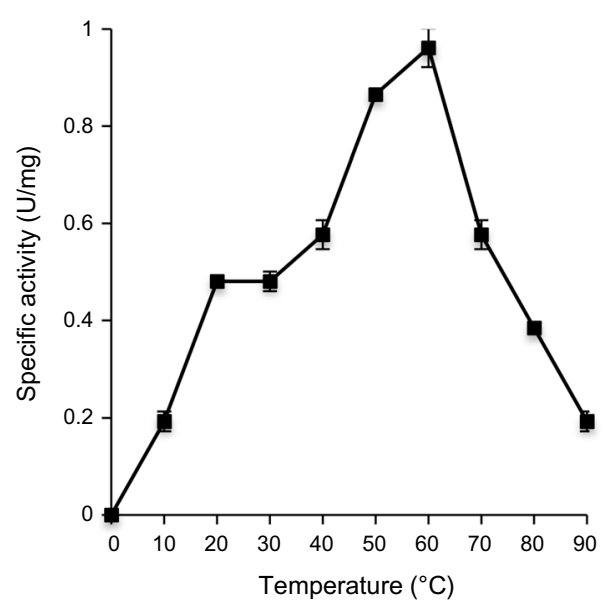

Fig. 7 Optimum temperature for lignin peroxidase with $n$-propanol as substrate. The experiment was done in duplicate and the values are expressed as mean \pm SD

\section{Discussion}

Bacterial enzymes play an important role in transformation of metal ions to nanoparticles. Nitrate reductase, amylase, urease, aspartate protease and laccase have been demonstrated to synthesize silver, gold, copper, platinum and other metal nanoparticles (Duran et al. 2015; Reith et al. 2012; Sanghi et al. 2011; Shedbalkar et al. 2014). In present study, we have purified and characterized the enzyme responsible for extracellular AgNP synthesis in Acinetobacter sp. MCC 3391. Positive lignin peroxidase activity in SE extract confirmed that the bacteria secrete enzymes and other biomolecules extracellularly, which may act as reducing agent to convert silver ions to AgNPs. Lignin peroxidase is present mainly in fungi, such as Phanerochaete chrysosporium, Gloeophyllum sepiarium and Cladosporium herbarum and acts to degrade lignin (Yadav et al. 2010; Wang et al. 2008). However, few bacteria, such as Acinetobacter calcoaceticus, Brevibacillus laterosporus and Streptomyces viridosporus, are also known to produce lignin peroxidase (Ghodake et al. 2009; Gomare et al. 2008; Nascimento and Silva 2008). Our results, with respect to presence of nitrate reductase in Acinetobacter sp., is in accordance with the study of Gaidhani et al. (2013), where nitrate reductase independent synthesis of AgNPs was reported.

Employing two-step purification of the enzyme present in SE extract, through DEAE-cellulose anion exchanger and Biogel P-150 gel filtration column chromatography, 6.5-fold purified fraction was obtained with specific activity of $1.571 \mathrm{U} / \mathrm{mg}$. Our results showed lower purification as compared to Ghodake et al. (2009), where 72-fold purification was reported employing only DEAEcellulose chromatography. In a similar study, Kalyani et al. (2011) reported 17.1-fold purification for peroxidase enzyme from Pseudomonas sp. SUK1. Single protein band of the fraction observed on native-PAGE confirmed the purity of the fraction whereas two bands on SDSPAGE indicated the tetrameric nature of lignin peroxidase in which two dimers, having molecular weight of approximately $47.8(=2 \times 23.9)$ and $49.2(=2 \times 24.6)$ $\mathrm{kDa}$, are joined together. Dimeric nature of lignin peroxidase in A. calcoaceticus NCIM 2890 has been suggested earlier, where the molecular mass of the enzyme was reported to be $110 \mathrm{kDa}$ (Ghodake et al. 2009). Other reports on bacterial peroxidases purified from Pseudomonas sp. SUK1 (Kalyani et al. 2011), Bacillus sp. VUS (Dawkar et al. 2009) and B. laterosporus MTCC 2298 (Gomare et al. 2008) showed molecular weights of 86, 43 and $205 \mathrm{kDa}$, respectively. On contrary, lignin peroxidase of Streptomyces sp. is a small protein of only $18 \mathrm{kDa}$ (Nascimento and Silva 2008).

Preliminary testing of AgNP synthesis by purified enzyme was done by visual observation. The change in color of the solution from colorless to reddish brown is well known for reduction of silver ions to AgNPs (Singh et al. 2013; Gaidhani et al. 2013). Besides this, a single SPR peak located between 400 and $440 \mathrm{~nm}$ indicates the formation of spherical nanoparticles of size $\leq 100 \mathrm{~nm}$ (Henglein 1993), as also confirmed by TEM and particle size distribution. According to Mie's theory, spherical metal nanoparticles produce single SPR peak while anisotropic particles, depending upon the shape, could give rise to two or more such bands (He et al. 2002; Novak and Feldheim 2000). In EDS spectrum, a peak at $3 \mathrm{keV}$ is typical for absorption of AgNPs due to SPR (Singh et al. 
Table 2 Effect of salts on activity of purified enzyme

\begin{tabular}{ll}
\hline Salts & Specific activity $\mathbf{( U / \mathbf { m g } )}$ \\
\hline Control (without salt) & 1.570 \\
Magnesium sulfate & 1.982 \\
Zinc sulfate & 1.040 \\
Copper sulfate & 1.648 \\
Ammonium sulfate & 0.127 \\
Silver chloride & 1.400 \\
Mercuric chloride & 1.400 \\
Calcium chloride & 1.400 \\
Sodium chloride & 1.400 \\
Silver nitrate & 1.451 \\
Sodium nitrate & 1.756 \\
Potassium nitrate & 1.410 \\
Ammonium nitrate & 0.062 \\
Sodium thiosulfate & 1.800 \\
Dipotassium hydrogen phosphate & 1.206 \\
Potassium dihydrogen phosphate & 1.217 \\
\hline
\end{tabular}

Table 3 Substrate specificity of purified lignin peroxidase

\begin{tabular}{ll}
\hline Substrates & Specific activity $\mathbf{( U / m g )}$ \\
\hline n-Propanol & 1.571 \\
Catechol & 1.361 \\
Guaiacol & 1.426 \\
Hydroxyquinone & $\mathrm{ND}$ \\
Veratryl alcohol & 1.127 \\
\hline
\end{tabular}

ND not detected

2013), thereby confirmed the transformation of silver ions to nano silver through purified lignin peroxidase enzyme. Majority of reports suggested the involvement of $\mathrm{NADH}$ and NADH-dependent nitrate reductase in bacteria mediated silver nanoparticle synthesis (Chauhan et al. 2013; Fayaz et al. 2011; Kalimuthu et al. 2008; Karthik et al. 2014; Srivastava et al. 2013). Moreover, Kumar et al. (2007) demonstrated the in vitro synthesis of AgNPs of size 10-25 nm employing pure $\alpha$-NADPH-dependent nitrate reductase. Besides this, other enzymes, such as cysteine desulfhydrase (C-S lyase), NfsA nitroreductase, oxidoreductase and phytochelatin synthase has also been implicated in reduction of metal ions to metal nanoparticles in microorganisms (Bai et al. 2011; Jha and Prasad 2010; Mohanpuria et al. 2008; Shahverdi et al. 2007). In one study, synthesis of enzymatically grown AgNPs has also been demonstrated, where a streptavidin-horseradish peroxidase (HRP) conjugate, bound to the silicon surface via DNA linker molecule, catalyzed the silver ion reduction (Schneidewind et al. 2012). However, this is the first study in Acinetobacter spp. to elucidate the involvement lignin peroxidase, secreted extracellularly, in transformation of silver ions.

Lignin peroxidase belongs to oxidoreductase family of enzymes, which does not require cofactors like NADH or NADPH. Here, the nanoparticle synthesis was obtained without addition of any peroxide derivative. This could be due to the presence of free cysteine in the enzyme. According to Glumoff et al. (1990), most lignin peroxidases possess five cysteine residues having sulfhydryl groups that may act as reducing agent. Besides this, hydroxyl group in tyrosine residue may also donate electron for reduction of silver ions to AgNPs. Sulfhydryl group in cysteine of laccase and urease enzymes, hydroxyl groups in tyrosine and amine groups in tryptophan residues of lysozyme have been suggested to play a significant role in formation of AgNPs through reduction of silver ions (Duran et al. 2014; Kumar et al. 2012; Sharma et al. 2013). Generation of nanosilver through functional groups of amino acid residues may affect the activity of the enzyme as also indicated by decrease in its specific activity on exposure to silver nitrate (Table 2). On contrary to our results, Rangnekar et al. (1997) described the amylase-mediated generation of gold nanoparticles through $\mathrm{Au}-\mathrm{S}$ bonds with retention of enzyme activity. However, complete elucidation of mechanism warrants further investigation.

The optimum $\mathrm{pH}$ purified enzyme that catalyzed $n$-propanol oxidation was found to be 2 , which is in accordance with the study of Dawkar et al. (2009). Peroxidase purified from Pseudomonas sp. and Bacillus sp. also exhibited maximum activity in acidic $\mathrm{pH}$ close to 3.0 (Kalyani et al. 2011). However, as reported earlier, AgNP synthesis occurs in $\mathrm{SE}$ extract at $\mathrm{pH} 7$ where $\mathrm{AgNO}_{3}$ acts as a substrate (Singh et al. 2013). This indicates that $\mathrm{pH}$ optimum and hence, the enzyme activity is dependent upon the substrate. Variation in $\mathrm{pH}$ of the reaction medium cause changes in the ionic forms of the active sites, which may result in change in enzyme activity and their three-dimensional structure (Hossain and Ananthraman 2006; Shulter and Kargi 2000). Moreover, in SE extract there are various other organic moieties, which help the enzyme to reduce silver ions to nanoparticles at neutral pH. In a similar finding, Ghodake et al. (2009) reported the optimum $\mathrm{pH}$ of lignin peroxidase enzyme to be 1 with $n$-propanol as substrate while dye decolorization by the enzyme occurred at $\mathrm{pH} 7$.

Lignin peroxidase activity with substrate $n$-propanol was observed at a broad range of temperature from 10 to $90{ }^{\circ} \mathrm{C}$ signifying its excellent thermostability. The optimum temperature for AgNP synthesis using bacterial SE extract was $70^{\circ} \mathrm{C}$ (Singh et al. 2013). In view of these 
facts, it is clear that the purified enzyme possess the ability to catalyze the reactions at high temperature and can be one of the proteins involved in AgNP synthesis from silver ions. Similar broad range temperature stability has been reported for lignin peroxidase enzymes purified from A. calcoaceticus NCIM 2890 (Ghodake et al. 2009) and B. laterosporus MTCC 2298 (Gomare et al. 2008). However, in contrary to our results, Kalyani et al. (2011) showed the maximum peroxidase activity at $40^{\circ} \mathrm{C}$, which reduced drastically at temperature above $40{ }^{\circ} \mathrm{C}$. Fungal lignin peroxidases exhibit temperature optimum in the range of $23-25{ }^{\circ} \mathrm{C}$ (Wang et al. 2008). In accordance with our study, magnesium sulfate and ammonium nitrate has been reported to act as lignin peroxidase activator and inhibitor, respectively (Kalyani et al. 2011). Manganese ions have also been reported to enhance the production of lignin peroxidase in Phanerochaete chrysosporium (Wang et al. 2008). Microbial peroxidases have wide substrate specificity and can easily interact with hydroxyl and methoxy-substituted phenols (Kim and Shoda 1999; Yang et al. 2005). Lignin peroxidase from $P$. chrysosporium showed maximum activity with ferrocyanide followed by $N, N$-dimethyl-1,4-phenylenediamine, anisyl alcohol, veratryl alcohol and guaiacol (Glumoff et al. 1990). Purified lignin peroxidase, in our study, also exhibited broad substrate specificity. However, the results are contradictory where we obtained higher activity with guaiacol than veratryl alcohol. It is well documented that lignin peroxidase in fungi degrades lignin with involvement of veratryl alcohol, which is a secondary metabolite and acts as a cofactor for the enzyme (Wang et al. 2008).

To summarize, we have purified lignin peroxidase from SE extract of Acinetobacter sp. and demonstrated its the involvement in synthesis of extracellular polydispersed spherical AgNP of $\sim 50 \mathrm{~nm}$. The purified enzyme is a $99 \mathrm{kDa}$ protein consisting of two dimers and showed the optimum $\mathrm{pH}$ and temperature activity at 2 and $60{ }^{\circ} \mathrm{C}$ with $n$-propanol as the favored substrate. Moreover, magnesium sulfate and silver nitrate act as activators of the enzyme while ammonium salts inhibited its activity. It is important to note that SE extract contains numerous organic molecules, which can act to reduce silver ions to AgNPs and lignin peroxidase is one of them. This explains the variation in size and dispersion observed during synthesis using SE extract and purified enzyme. Further characterization and sequencing of the purified lignin peroxidase should be done by mass spectrometry, which can be used for in silico studies. This study further enables designing rational strategy for enzymatic approach of rapid and effective nanoparticle synthesis with novel morphologies, surface properties and unique functions.

\section{Abbreviations}

AgNPs: silver nanoparticles; HRP: horseradish peroxidase; TEM: transmission electron microscope; EDS: energy dispersion spectroscopy; PAGE: polyacrylamide gel electrophoresis; NAD: nicotinamide adenine dinucleotide; NEDD: $\mathrm{N}$-(1-naphthyl)ethylenediamine dihydrochloride; SE: secreted enzymes; SPR: surface plasmon resonance.

\section{Authors' contributions}

RS and BAC conceived the project. US and SW contributed to experimental designing of protein purification through chromatography. RS and SN performed major experiments, analyzed and interpreted the results. All authors read and approved the final manuscript.

\section{Author details}

${ }^{1}$ Department of Microbiology, Savitribai Phule Pune University, Pune 411007, India. ${ }^{2}$ Department of Biochemistry, The Institute of Science, Mumbai 400032 , India. ${ }^{3}$ Dr. Babasaheb Ambedkar Marathwada University, Aurangabad 431004, India.

\section{Acknowledgements}

RS and SW acknowledge the support from University Grants Commission (UGC), New Delhi, India in the form of senior research fellowship. SN thanks Savitribai Phule Pune University (SPPU), Pune, India for research fellowship.

\section{Competing interests}

The authors declare that they have no competing interests.

Availability of data and materials

The datasets supporting the conclusions of this article are included within the article.

\section{Ethics approval and consent to participate}

This article does not contain any studies with human participants or animals performed by any of the authors.

\section{Funding}

This work was supported by University of Potential Excellence II (2012-2017) awarded to SP Pune University, Pune, India by University Grants Commission, New Delhi, India.

\section{Publisher's Note}

Springer Nature remains neutral with regard to jurisdictional claims in published maps and institutional affiliations.

Received: 7 June 2017 Accepted: 19 December 2017

Published online: 22 December 2017

\section{References}

Bai H-J, Yang B-S, Chai C-J, Yang G-E, Jia WL, Yi Z-B (2011) Green synthesis of silver nanoparticles using Rhodobacter sphaeroides. World J Microbiol Biotechnol 27:2723-2728

Brayner R, Barberousse H, Hemadi M, Djediat S, Yepremian C, Coradin T, Livage J, Fievet F, Coute A (2007) Cyanobacteria as bioreactors for the synthesis of $\mathrm{Au}, \mathrm{Ag}, \mathrm{Pd}$, and Pt nanoparticles via an enzyme-mediated route. J Nanosci Nanotechnol 7:2696-2708

Chauhan R, Kumar A, Abraham J (2013) A biological approach to the synthesis of silver nanoparticles with Streptomyces sp. JAR1 and its antimicrobial activity. Sci Pharm 81:607-621

Das SK, Marsili E (2010) A green chemical approach for the synthesis of gold nanoparticles: characterization and mechanistic aspect. Rev Environ Sci Biotechnol 9:199-204

Dawkar W, Jadhav UU, Telke AA, Govindwar SP (2009) Peroxidase from Bacillus sp. VUS and its role in the decolorization of textile dyes. Biotechnol Bioprocess Eng 14:361-368

Deshpande LM, Chopade BA (1994) Plasmid mediated silver resistance in Acinetobacter baumannii. Biometals 7:49-56 
Deshpande LM, Kapadnis BP, Chopade BA (1993) Metal resistance in Acinetobacter and its relation to $\beta$-lactams production. Biometals 6:55-59

Dhakephalkar PK, Chopade BA (1994) High levels of multiple metal resistance and its correlation to antibiotic resistance in environmental isolates of Acinetobacter. Biometals 7:67-74

Duran N, Marcato PD, Duran M, Yadav A, Gade A, Rai M (2011) Mechanistic aspects in the biogenic synthesis of extracellular metal nanoparticles by peptides, bacteria, fungi and plants. Appl Microbiol Biotechnol 90:1609-1624

Duran N, Cuevas R, Cordi L, Rubilar O, Diez MC (2014) Biogenic silver nanoparticles associated with silver chloride nanoparticles (Ag@AgCl) produced by laccase from Trametes versicolor. Springerplus 3:645

Duran M, Silveira CP, Duran N (2015) Catalytic role of traditional enzymes for biosynthesis of biogenic metallic nanoparticles: a mini-review. IET Nanobiotechnol 9:314-323

Fayaz AM, Girilal M, Rahman M, Venkatesan R, Kalaichelvan PT (2011) Biosynthesis of silver and gold nanoparticles using thermophilic bacterium Geobacillus stearothermophilus. Process Biochem 46:1958-1962

Gaidhani S, Singh R, Singh D, Patel U, Shevade K, Yeshvekar R, Chopade BA (2013) Biofilm disruption activity of silver nanoparticles synthesized by Acinetobacter calcoaceticus PUCM 1005. Mater Lett 108:324-327

Ghodake GS, Kalme SD, Jadhav JP, Govindwar SP (2009) Purification and partial characterization of lignin peroxidase from Acinetobacter calcoaceticus NCIM 2890 and its application in decolorization of textile dyes. Appl Biochem Biotechnol 152:6-14

Glumoff T, Harvey PJ, Molinari S, Goble M, Frank G, Palmer JM, Smit JDG, Leisola MSA (1990) Lignin peroxidase from Phanerochaete chrysosporium. Molecular and kinetic characterization of isozymes. Eur J Biochem 187:515-520

Gomare SS, Jadhav JP, Govindwar SP (2008) Degradation of sulfonated azo dyes by the purified lignin peroxidase from Brevibacillus laterosporus MTCC 2298. Biotechnol Bioprocess Eng 13:136-143

He R, Qian X, Yin J, Zhu Z (2002) Preparation of polychrome silver nanoparticles in different solvents. J Mater Chem 12:3783-3786

Henglein A (1993) Physicochemical properties of small metal particles in solution: microelectrode reactions, chemisorption, composite metal particles, and the atom-to-metal transition. J Phys Chem B 97:5457-5471

Hossain MS, Ananthraman N (2006) Activity enhancement of ligninolytic enzymes of trametes versicolor with bagasse powder. Afr J Biotechnol 5:189-194

Hosseini-Abari A, Emtiazi G, Ghasemi SM (2013) Development of an ecofriendly approach for biogenesis of silver nanoparticles using spores of Bacillus athrophaeus. World J Microbiol Biotechnol 29:2359-2364

Huddedar SB, Shete AM, Tilekar JN, Gore SD, Dhavale DD, Chopade BA (2002) Isolation, characterization and plasmid pUPI126-mediated indole-3-acetic acid production in Acinetobacter strains from rhizosphere of wheat. Appl Biochem Biotechnol 102-103:21-39

Jagtap S, Yavankar SP, Pardesi KR, Chopade B (2010) Production of bioemulsifier from Acinetobacter spp. from human skin of tribal population. Indian J Exp Biol 48:70-76

Jha AK, Prasad K (2010) Biosynthesis of metal and oxide nanoparticles using Lactobacilli from yoghurt and probiotic spore tablets. Biotechnol J 5:285-291

Kalimuthu K, Suresh Babu R, Venkataraman D, Bilal M, Gurunathan S (2008) Biosynthesis of silver nanocrystals by Bacillus licheniformis. Colloids Surf B Biointerfaces 65:150-153

Kalyani DC, Phugare SS, Shedbalkar UU, Jadhav JP (2011) Purification and characterization of a bacterial peroxidase from the isolated strain Pseudomonas sp. SUK1 and its application for textile dye decolorization. Ann Microbiol 61:483-491

Karthik L, Kumar G, Kirthi AV, Rahuman AA, Bhaskara Rao KV (2014) Streptomyces sp. LK3 mediated synthesis of silver nanoparticles and its biomedical application. Bioprocess Biosyst Eng 37:261-267

Kim SG, Shoda M (1999) Purification and characterization of a novel peroxidase from Geotrichum candidum Dec 1 involved in decolorization of dyes. Appl Environ Microbiol 65:1029-1035

Kumar SA, Abyaneh MK, Gosavi SW, Kulkarni SK, Pasricha R, Ahmad A, Khan MI (2007) Nitrate reductase-mediated synthesis of silver nanoparticles from $\mathrm{AgNO}_{3}$. Biotechnol Lett 29:439-445

Kumar U, Ranjan AK, Sharan C, Hardikarc AA, Pundle A, Poddar P (2012) Green approach towards size controlled synthesis of biocompatible antibacterial metal nanoparticles in aqueous phase using lysozyme. Curr Nanosci 8:130-140

Lowry O, Rosbrough N, Farr A, Randall RJ (1951) Protein measurement with the folin phenol reagent. J Biol Chem 193:265-275

Mohanpuria P, Rana NK, Yadav SK (2008) Biosynthesis of nanoparticles: technological concepts and future applications. J Nanopart Res 10:507-517

Nascimento HJ, Silva JG Jr (2008) Purification of lignin peroxidase isoforms from Streptomyces viridosporus T7A by hydrophobic based chromatographies. World J Microbiol Biotechnol 24:1973-1975

Novak JP, Feldheim DL (2000) Assembly of phenylacetylene bridged silver and gold nanoparticle arrays. J Am Chem Soc 122:3979-3980

Pardesi KR, Yavankar SP, Chopade BA (2007) Plasmid distribution and antimicrobial susceptibility patterns of Acinetobacter genospecies from healthy skin of a tribal population in western India. Indian J Med Res 125:79-88

Patil JR, Chopade BA (2000) Distribution and in vitro antimicrobial susceptibility of Acinetobacter species on the skin of healthy humans. Natl Med J India 14:204-208

Rangnekar A, Sarma TK, Singh AK, Deka J, Ramesh A, Chattopadhyay A (1997) Retention of enzymatic activity of a-amylase in the redictive synthesis of gold nanoparticles. Langmuir 23:5700-5706

Reith F, Stewart L, Wakelin SA (2012) Supergene gold transformation: secondary and nano-particulate fold from southern New Zealand. Chem Geol 320-321:32-45

Rokhbakhsh-Zamin F, Sachdev D, Kazemi-Pour N, Engineer A, Pardesi KR, Zinjarde S, Dhakephalkar PK, Chopade BA (2011) Characterization of plant-growth-promoting traits of Acinetobacter species isolated from rhizosphere of Pennisetum glaucum. J Microbiol Biotechnol 21:556-566

Sachdev D, Nema P, Dhakephalkar P, Zinjarde S, Chopade B (2010) Assessment of $16 \mathrm{~S}$ rRNA gene-based phylogenetic diversity and promising plant growth-promoting traits of Acinetobacter community from the rhizosphere of wheat. Microbiol Res 165:627-638

Saha SC, Chopade BA (2002) Effect of food preservatives on Acinetobacter genospecies isolated from meat. J Food Sci Technol 39:26-32

Sanghi R, Verma P, Puri S (2011) Enzymatic formation of gold nanoparticles using Phanerochaete chrysosporium. Adv Chem Eng Sci 1:154-162

Schneidewind H, Schuler T, Strelau KK, Weber K, Caialla D, Diegel M, Mattheis R, Berger A, Moller R, Popp J (2012) The morphology of silver nanoparticles by enzyme-induced reduction. Beilstein J Nanotechnol 3:404-414

Shahverdi AR, Minaeian S, Shahverdi HR, Jamalifar H, Nohi AA (2007) Rapid synthesis of silver nanoparticles using culture supernatants of Enterobacteria: a novel biological approach. Process Biochem 42:919-923

Shakibai MR, Dhakephalkar PK, Kapadnis BP, Chopade BA (1998) Plasmid mediated silver and antibiotic resistance in Acinetobacter baumannii BL54. Iran J Med Sci 23:30-36

Shakibai MR, Kapadnis BP, Dhakephalkar PK, Chopade BA (1999) Removal of silver from photographic wastewater effluent using Acinetobacter baumannii BL54. Can J Microbiol 45:995-1000

Shakibai MR, Dhakephalkar PK, Kapdnis BP, Chopade BA (2003) Silver resistance in Acinetobacter baumannii BL54 occurs through binding to a Ag-binding protein. Iranian J Biotechnol 1:41-46

Sharma S, Mandani S, Sarma TK (2013) Biogenic growth of alloys and core-shell nanostructures using urease as a nanoreactor at ambient condition. Sci Rep 3:1-8

Shedbalkar U, Singh R, Wadhwani S, Gaidhani S, Chopade BA (2014) Microbial synthesis of gold nanoparticles: current status and future prospects. Adv Colloid Interface Sci 209:40-48

Shulter ML, Kargi F (2000) Bioprocess engineering basic concept. Prentice Hall of India Pvt Ltd, India

Singh R, Wagh P, Gaidhani S, Kumbhar A, Bellare J, Chopade BA (2013) Synthesis, optimization and characterization of silver nanoparticles from Acinetobacter calcoaceticus and their enhanced antibacterial activity when combined with antibiotics. Int J Nanomed 8:4277-4290

Singh R, Shedbalkar UU, Wadhwani SA, Chopade BA (2015) Bacteriagenic silver nanoparticles: synthesis, mechanism and applications. Appl Microbiol Biotechnol 99:4579-4593

Singh R, Nadhe S, Wadhwani S, Shedbalkar U, Chopade BA (2016) Nanoparticles for control of biofilms of Acinetobacter species. Materials 9:383. https://doi.org/10.3390/ma9050383

Srivastava P, Bragança J, Ramanan SR, Kowshik M (2013) Synthesis of silver nanoparticles using haloarchaeal isolate Halococcus salifodinae $\mathrm{BK}_{3}$. Extremophiles 17:821-831 
Towner KJ, Chopade BA (1987) Biotyping of Acinetobacter calcoaceticus using the API 2ONE system. J Hosp Infect 10:145-151

Wadhwani SA, Shedbalkar UU, Singh R, Karve MS, Chopade BA (2014) Novel polyhedral gold nanoparticles: green synthesis, optimization and characterization by environmental isolate of Acinetobacter sp. SW30. World J Microbiol Biotechnol 30:2723-2731

Wadhwani SA, Shedbalkar UU, Singh R, Vashisth P, Pruthi V, Chopade BA (2016) Kinetics of synthesis of gold nanoparticles by Acinetobacter sp. SW30 isolated from environment. Indian J Microbiol 56:439-444

Wang P, Hu X, Cook S, Begonia M, Lee KS, Hwang H-M (2008) Effect of culture conditions on the production of ligninolytic enzymes by white rot fung Phanerochaete chrysosporium (ATCC 20696) and separation of its lignin peroxidase. World J Microbiol Biotechnol 24:2205-2212
Yadav RSS, Patel VK, Yadav KDS, Sharma JK, Singh NP (2010) Lignin peroxidases of some indigeneous ligninolytic fungi: secretion and enzymatic characteristics. Indian J Microbiol 50:132-138

Yang JS, Yuan H, Wang HX, Chen WX (2005) Purification and characterization of lignin peroxidases from Penicillium decumbens P6. World J Microbiol Biotechnol 21:435-440

Yavankar SP, Pardesi KR, Chopade BA (2007) Species distribution and physiological characterization of Acinetobacter genospecies from healthy human skin of tribal population in India. Indian J Med Microbiol 25:336-345

Yele AB, Thawal ND, Sahu PK, Chopade BA (2012) Novel lytic bacteriophage AB7-IBB1 of Acinetobacter baumannii: isolation, characterization and its effect on biofilm. Arch Virol 157:1441-1450

\section{Submit your manuscript to a SpringerOpen ${ }^{\circ}$ journal and benefit from:}

- Convenient online submission

- Rigorous peer review

- Open access: articles freely available online

- High visibility within the field

Retaining the copyright to your article

Submit your next manuscript at $\boldsymbol{\nabla}$ springeropen.com 